\title{
Mykolaiv Sands in Opole Minor and beyond: sedimentary features and biotic content of Middle Miocene (Badenian) sand shoals of Western Ukraine
}

\author{
Anna WYSOCKA, Andrzej RADWAŃSKI and Marcin GÓRKA
}

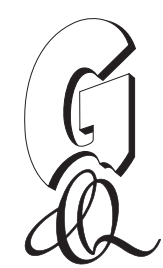

\begin{abstract}
Wysocka A., Radwański A. and Górka M. (2012) - Mykolaiv Sands in Opole Minor and beyond: sedimentary features and biotic content of Middle Miocene (Badenian) sand shoals of Western Ukraine. Geol. Quart., 56 (3): 475-492, doi: 10.7306/gq.1034

The Mykolaiv Sands are a huge lithosome of Middle Miocene (Badenian) age, accommodated within the Fore-Carpathian Basin in the Western Ukraine. Typically developed in the area of Opole Minor, it spreads across adjacent regions of Opole to cover an area of about $1300 \mathrm{~km}^{2}$. The varied sedimentary structures and ubiquitous burrows, indicate their development as a stack of sand shoals or related bodies, up to a few tens of metres thick, some of which temporarily reached sea level. Amidst the shoals, storm scours intermittently formed channel-like infills, some with residual lags at the base. The reversed density stratification and/or an increasing gravity gradient involved mass movements, some of which may have been triggered by seismic shocks focused at the shore or the adjacent hinterland of Podolia and Volhynia. Special attention is paid to the diverse fossils, all taphonomically filtered (aragonite shells and chitinous carapaces being lost), but which locally are mass-aggregated. They typify particular sand sets/bodies, to form allochthonous assemblages, some members of which (the cirripedes Scalpellum and Creusia, the shark Hemipristis, the ray Myliobatis) are newly recognized in the Ukrainian part of the Fore-Carpathian Basin. The others enrich considerably the faunal content of the Middle Miocene (Badenian) Paratethyan basins, either in terms of taxonomic diversity, or the eco-taphonomy of selected taxa (the starfish Astropecten, diverse echinoids). The whole faunal content of the Mykolaiv Sands may owe its profuse development to the global Middle Miocene Climatic Optimum of early Badenian age.
\end{abstract}

Anna Wysocka, Andrzej Radwański and Marcin Górka, Institute of Geology, University of Warsaw, Żwirki i Wigury 93, 02-089 Warszawa,Poland,e-mails: anna.wysocka@uw.edu.pl,magurka@uw.edu.pl (received: April 3,2012; accepted: May 29, 2012; first published online: August 29, 2012).

Key words: Western Ukraine, Middle Miocene (Badenian), eco-taphonomy, burrows, depositional structures, sedimentology.

\section{INTRODUCTION}

The enormous accumulation of the Middle Miocene (Badenian) Mykolaiv Sands in Western Ukraine has long been known (Niedźwiedzki, 1879; Hilber, 1882; Łomnicki, 1897, 1898; Jahn, 1937; Malicki and Jahn, 1937; Teisseyre, 1938; Pazdro, 1953; Kudrin, 1966; Wysocka and Jasionowski, 2006), but never systematically described. This lack of interest has supposedly been caused by the paucity, or absence, of body fossils which occur abundantly in other coeval sands spreading widely throughout Western Ukraine. The sand-mass in question, typically developed around the small city of Mykolaiv (south of Lviv), situated near the valley of the Dnister River in the south, extends northwards as far as the vicinity of Lviv (Fig. 1). In their southern part, near Mykolaiv, the sands are poorly exposed along the slopes of gentle hills, and are covered by arable soil or forested, elsewhere. Their study has involved access to many commercial sand-pits or quarries established in recent decades. When the present authors started with their investigation (Radwański and Wysocka, 2001), it appeared that the Mykolaiv Sands contained a well-nigh inexhaustible spectrum of sedimentary structures, both of physical and of biogenic origin. Moreover, their content of body fossils turned out to be not as scarce as thought formerly (see Radwański et al., 2012).

The Mykolaiv Sands, as an informal lithostratigraphical unit, was distinguished by Petryczenko et al. (1994, fig. 2) and, as such, is used in the present paper.

\section{REGIONAL SETTING}

The Mykolaiv Sands extend from the southwestern margin of the East European Platform to border the tectonically active Carpathian Foredeep (Fig. 1). They rests upon a Laramide basement of Upper Cretaceous (Maastrichtian) marls, the to- 


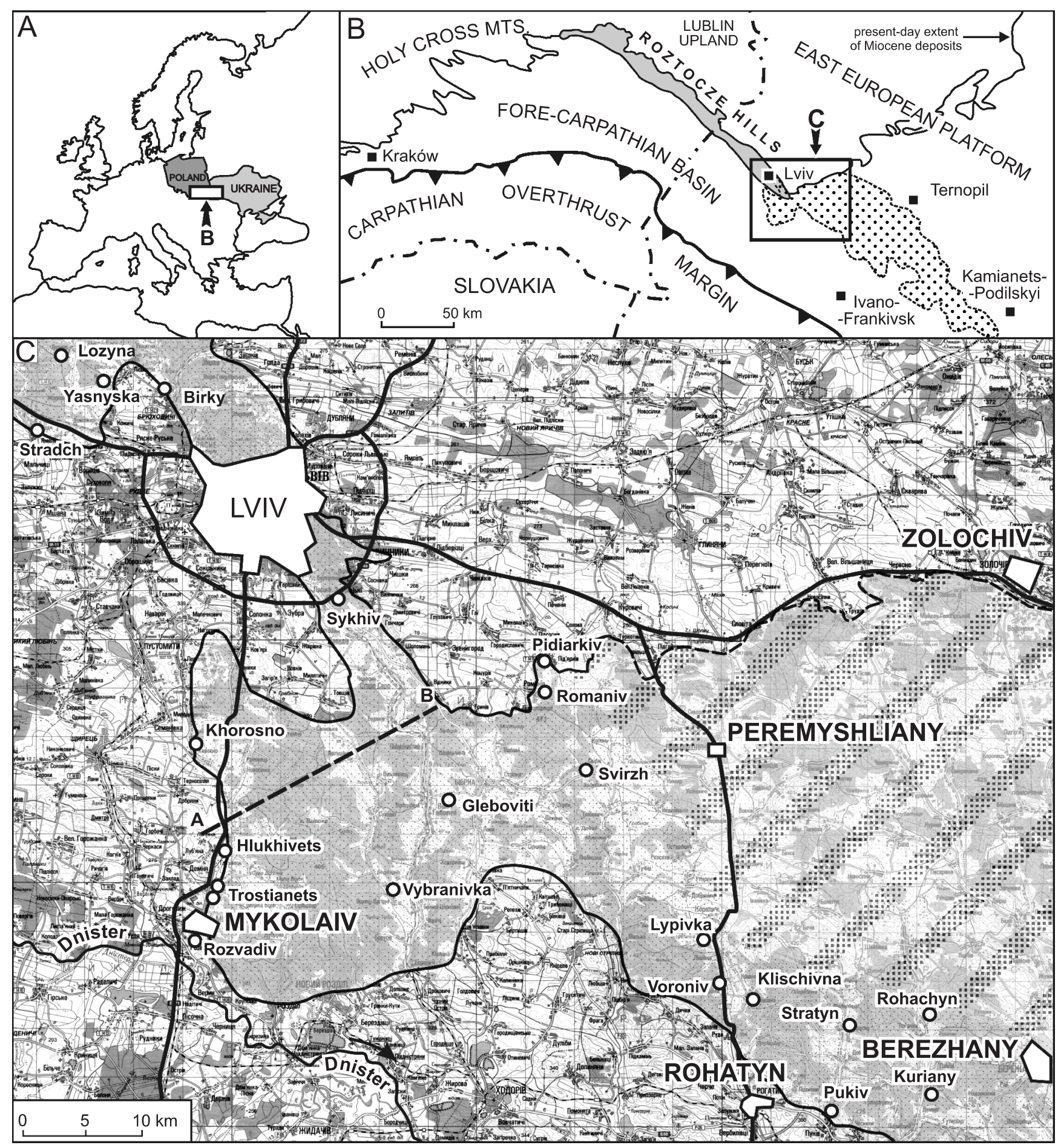

Fig. 1. Regional location of the Mykolaiv Sands studied

A - general setting of the region studied (B) in Europe; B - part of the Fore-Carpathian Basin in Poland and Western Ukraine, to show the Middle Miocene (Badenian) sequences of the Roztocze Hills (shaded) and Opole regions (dotted); indicated is the present-day extent of Miocene deposits upon the East European Platform; C - topographic map of the Opole Minor region (rectangled in Fig. 1B), to show the extent of the Mykolaiv Sands (shaded) and their key exposures; hachured is the area beyond the well-defined sands in the Middle Miocene (Badenian) sequence, and carpeted by a Quaternary cover ( $c f$. Kudrin, 1966); A-B line of section in Figure 2

pography of which was sculpted by Paleogene erosion and denudation. The resultant pre-Miocene relief, being locally exposed today, is estimated at up to, or slightly over, one hundred metres (Pazdro, 1953, p. 26). The depressions in this were filled more or less completely with the Mykolaiv Sands, the thickness of which ranges, consequently, from zero to one hundred metres.

The sequence overlying the Mykolaiv Sands, that is the red-algal (lithothamnian) limestones, produced in Western Ukraine a regional key-horizon (the Mid-Lithothamnian Horizon of Alth, 1850 and many subsequent authors). In places 
where the Mykolaiv Sands are absent, theses limestones rest directly upon the Upper Cretaceous basement. On the other hand, the regionally uniform sequence of Mykolaiv Sands differs from other sand bodies of the Lviv region (Lomnicki, 1897, 1898; Wysocka, 2002), as well as of sand aprons on the Medobory Range to the east (Hilber, 1882; Radwański et al., 2006).

In geographical terms, the region of the typical occurrence of Mykolaiv Sands has been specified as Opole Minor (in Polish: Opole Mniejsze, see Pazdro, 1953), to distinguish it from other parts of the Opole regions. Nevertheless, in the present paper, the extent of the Mykolaiv Sands is greater than the extent of Opole Minor, covering some $600 \mathrm{~km}^{2}$ to include northerly the region of Lviv, classified formerly as the Roztocze Hills (Radwański and Wysocka, 2001; Wysocka, 2002). Together with a part of the Dnister Opole, also included herein, the entire of extent the Mykolaiv Sands attains an area of about $1300 \mathrm{~km}^{2}$ (see Fig. 1).

\section{STRATIGRAPHICAL AGE}

Although the Miocene stratigraphy of Ukraine is disputed, there is a general agreement to locate the Mykolaiv Sands and their biotic content in the lower Badenian (see Petryczenko et al., 1994; Peryt and Peryt, 1994; Harzhauser et al., 2003; Kroh, 2005, 2007; Radwański et al., 2006, p. 99).

The Mykolaiv Sands is thought coeval with the classical Korytnica sequence in Poland (see Bałuk and Radwański, 1977; Radwański et al., 2006), as well as with a part at least of the Badenian stratotype at the Baden-Sooss section in the Vienna Basin (see Rögl et al., 2008). Less obviously the foraminiferal (lagenid) ecozonation of the Central Paratethys may be applied to the Mykolaiv Sands, though this is not clearly compatible with the calcareous nannoplankton dating of the Polish part of the Fore-Carpathian Basin (see Rögl and Brandstätter, 1993, pp. 142-144).

\section{OVERALL LITHOLOGY OF SANDS}

The petrographic content of the Mykolaiv Sands is very monotonous, being composed of quartz with variable but minor admixtures of glauconite, clay minerals (illite and/or folidoide), as well as calcareous mud and bioclasts. All these accessories may locally dominate, to form intercalations of sandy marl or limestone. The clay content, when moistened, gives rise to a gray-greenish hue of variable extinction, in places reminiscent of glauconite, true grains of which occur solely in the pure sand. Most of the layers, regardless to their thickness which ranges from centimetres up to ten metres at Sykhiv, are more or less unconsolidated.

All the bioclasts are calcitic, aragonitic ones having been completely leached during diagenesis. Moreover, the larger bioclasts are heavily armoured with sand grains due to pressure-solution (see Radwański and Wysocka, 2001; Radwański et al., 2012).

The calcite-cemented sand layers appear in particular parts of some sections (e.g., at Stratyn), and their structural and biogenic content allows interpretion as beachrock (Radwański et al., 2012).

A diagenetic supply of silica is indicated by the preservation, in unconsolidated quartz sands, of silicified wood fragments of variable shape and size (see below). Not discussed herein are local occurrences of compact quartzites, used as building materials a century ago, and interpreted by Pazdro (1953) as having formed via silica supply through tectonic fissures.

\section{THE THICKNESS OF SANDS AND THEIR ACCESSIBILITY}

The thickness of the Mykolaiv Sands, nowhere exposed in total, has been estimated as up to several tens of metres (Łomnicki, 1897, p. 35), up to $40 \mathrm{~m}$, rarely to $90 \mathrm{~m}$ (Teisseyre, 1938, p. 115), or up to $60 \mathrm{~m}$ (Pazdro, 1953, p. 35). But, if post-Miocene block-faulting tectonics is taken into account (see Pazdro, 1953, fig. 9; and Fig. 2 herein), these figures must be reduced to almost a half. That is, 20 to 45 metres at maximum.

At present, the new sand exposures show sections up to 20 metres thick (Fig. 3), resulting from the logistics of quarrying, groundwater seepages included (e.g., at Stradch). Where a thicker sequence was met by deeper quarrying, its lower parts are now abandoned and covered with scree (e.g., at Stratyn, see Radwański et al., 2012).

In most sections studied, the exposed sequence of the Mykolaiv Sands represents its terminal part, topped by the

A

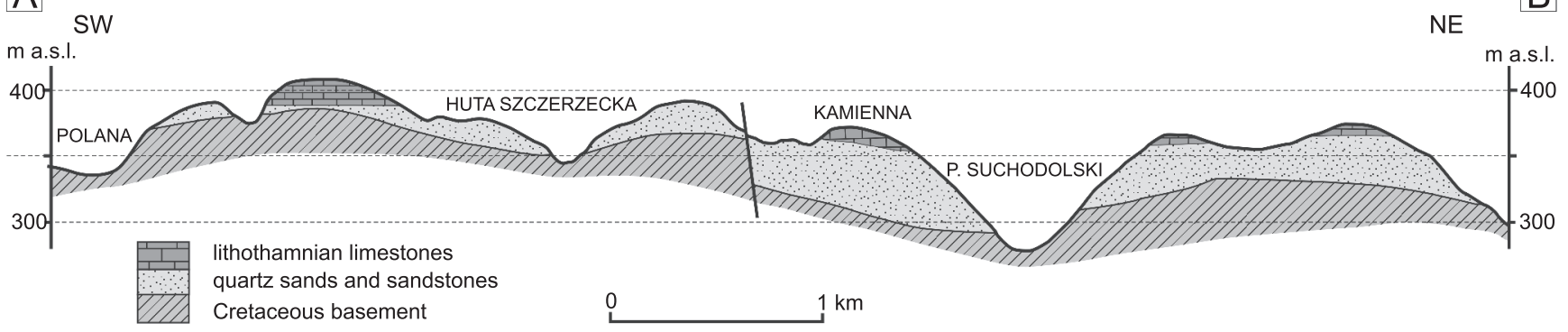

Fig. 2. Generalized section through Opole Minor (A-B line in Fig. 1), to show the Middle Miocene (Badenian) sequences overlying the Cretaceous basement; adapted from Pazdro (1953, fig. 9) 

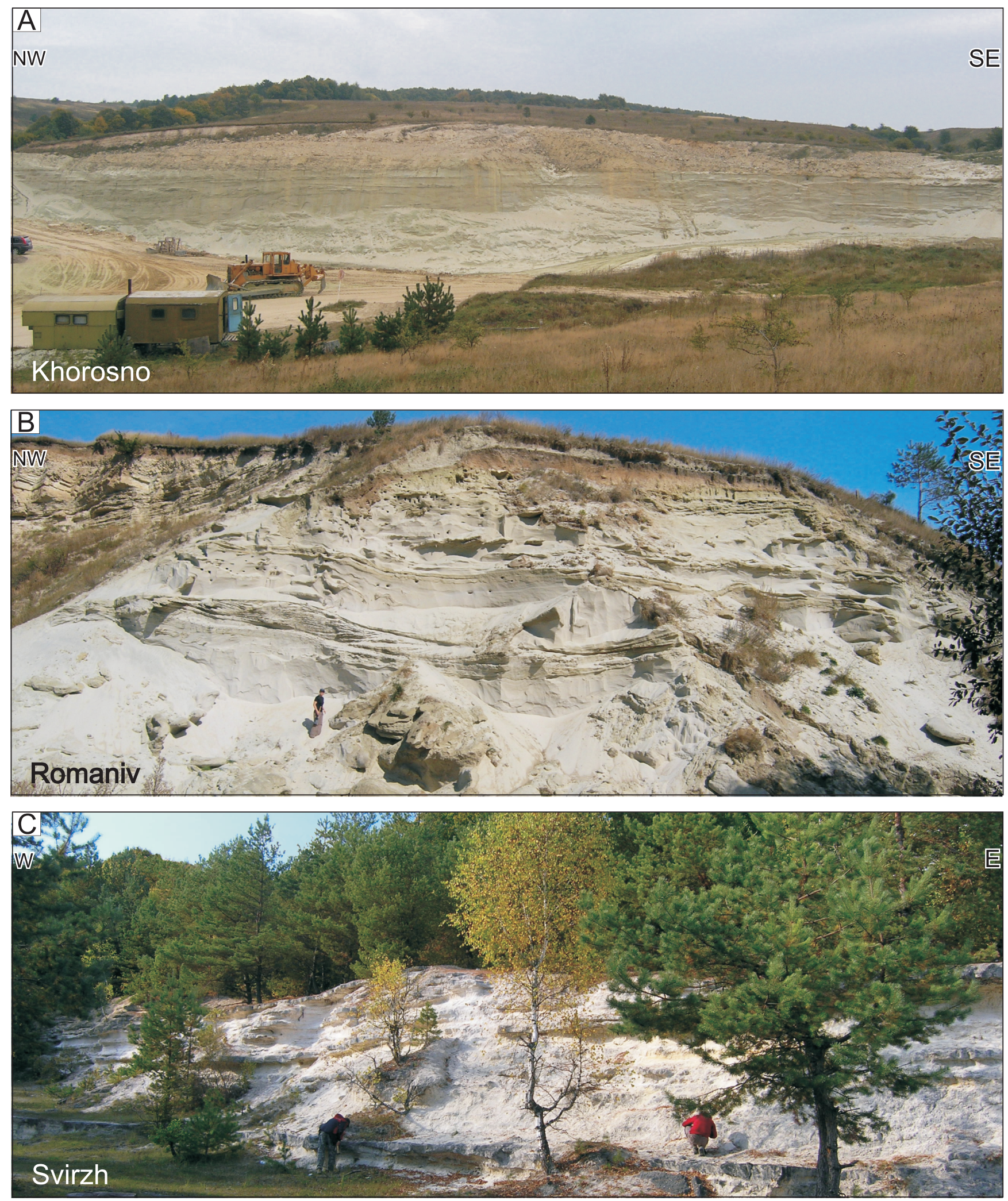

Fig. 3. Typical exposures of the Mykolaiv Sands

A - Khorosno - intense quarrying: the entire hill is to be exploited; B - Romaniv - local quarrying along a stream escarpment; $\mathbf{C}$ - Swirzh - local quarrying by the road running through a forested hill 
lithothamnian limestones or locally by the Ratyn Limestones (see Peryt and Peryt, 1994). Only one section, at Gleboviti near Bibrka, carries both the lithothamnian limestones at the top and in situ coniferan stumps (silicified) indicative of preserved ground level (Radwański and Wysocka, 2001). The thickness of that section, measuring some 12 metres, is reduced, having accumulated on a hummock of the Cretaceous basement that was named the Bibrka-Mykolaiv range (Teisseyre, 1938; Pazdro, 1953).

\section{REVIEW OF SEDIMENTARY FEATURES}

The Mykolaiv Sands comprise a complex and variable array of units/sets, most stratified, but some unstratified. Within particular units/sets, both depositional and deformational sedimentary structures are present, of variable height/thickness, and commonly burrowed. The most common types of structures are reviewed herein, to demonstrate their diversity, frequency in a unit/set, and relation to the adjacent strata in a section (Table 1 and Fig. 4).

Directional structures are not constantly oriented. Their range of directions, regardless to the size of units/sets (Fig. 4A-D) includes all sectors except the north. The largest cross-sets, with straight or concave foreset laminae tend to be oriented south-westerly (Fig. 4A).

Within the sand-pit exposures accessible, particular units/sets change laterally into, or interfinger with, the sandy units/sets of other structures across very short distances. Change also takes usually place vertically, where particular units/sets are stacked one above the other in variable successions, and no preferred trend is seen through the whole sequence of the Mykolaiv Sands.

The sedimentological data recognized allow interpretation of the depositional bodies as migrating megaripples of various kinds, sand bars, slumps, and/or delta-slope bodies. All of these are of a varying size/extent, accommodate with, or complementing, the bottom morphologies of formerly deposited bedforms. On a regional scale, the particular units/sets of sand bodies are therefore irregularly distributed, and the vertical sequences differ markedly from one section to an other.

The biogenic structures, being burrows of various kinds, are present in all units/sets of each section, except for the largest cross-bedded or structureless sand bodies.

The deformational structures are recognized to have formed by various mechanisms (Table 1), some caused, or triggered, by seismic shocks.

\section{GENERAL BIOTIC CONTENT OF THE MYKOLAIV SANDS}

\section{THE FLORAL CONTENT}

Apart from the ubiquitous marine red-algae Lithothamnium and its allies, forming either nodules or detritus in the sands, and becoming rock-building in the limestones overlying the sands, locally there are terrestrial plant remains. Although sporadic, they are diverse, represented by coalified detritus, locally fine-grained, compressed fragments in casts, as well as smaller or larger pieces of silicified driftwood, all undeterminable, but the latter occasionally bored by Teredo (see Łomnicki, 1897, 1898).

The new findings include examples of driftwood completely crumbled away, but the hollow casts containing sandy, internal moulds (steinkerns) of tubes of teredinid bivalves (Fig. 5E).

There are rare, spectacular silicified stumps of taxodiacean conifers, over one metre in diameter, and preserved in situ at Gleboviti (see Fig. 5F; Radwański and Wysocka, 2001, fig. 4 and pl. 1, fig. 1). Large, rounded boulders of such wood occur also at Stradch.

There are, too, scattered small pieces of amber (succinite), long noted since a report by Kner in 1851 (see Łomnicki, 1897; Srebrodolski, 1980).

\section{THE FAUNAL CONTENT}

All recognized faunal elements in the Mykolaiv Sands (see Figs. 5 and 6 ) belong to open-marine taxa, living in waters of full salinity, as first noted by Niedźwiedzki (1879) and Hilber (1882). Oligohaline and/or brackish elements are lacking. Of terrestrial groups, no fossil fragments (like bones, teeth, antlers, etc.) have been found. All preserved biota are calcitic, aragonitic and/or chitinous ones having been totally been removed during diagenesis. Some of the latter can, however, be recognized by the more or less cemented burrows constructed, and preserved, in loose sands (of sea anemones, polychaetes, crabs and shrimps, echinoids, and holothurians - see Table 1). Exceptionally preserved also are the sand-built internal moulds (steinkerns) of some bivalves, either of their shells, or their siphonal tubes, as well as the calcitic collars of such tubes (see below).

The calcite-shelled biota, sporadic or missing in some layers, become very common in others, to produce local mass-occurrences. This concerns primarily the echinoderms, both echinoids and starfish (Fig. 5A-D), the scanty former reports of which (Niedźwiedzki, 1879; Hilber, 1882; Łomnicki, 1897, 1898; Szörényi, 1953; Kudrin, 1957a; Kroh, 2005) contrast with their ubiquitous recognition presently (Radwański and Wysocka, 2001).

Of the calcitic bivalves, the most common are the isolated valves of small scallops (?various species) and oyster detritus. The latter is derived from a smooth-shelled small species, regarded as endemic, Neopycnodonte leopolitana (Niedźwiedzki, 1909), and discussed formerly (Radwański and Wysocka, 2004, pp. 390, 391). The large scallop Macrochlamis nodosiformis (de Serres in Pusch, 1837) is not uncommon at Khorosno; its taxonomy follows that one recently revised by Mandic (2004).

The cirripedes, apart from a single report of ?Poecilasma from Pidiarkiv (Reuss, 1864, pl. 2, fig. 12), classified by Withers $(1953$, pp. 340, 341) as Trilasmis (Poecilasma) miocaenicum (Reuss, 1864), are represented by numerous Scalpellum at Khorosno, and rarely by the coral-inhabiting 
The main bodies of the Mykolaiv Sands, and their facies significance

\begin{tabular}{|c|c|c|c|}
\hline \multirow{7}{*}{ 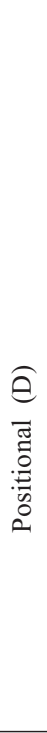 } & Structures & Characteristics & Interpretation \\
\hline & $\begin{array}{l}\text { large-scale tabular cross- } \\
\text { stratification, occasionally } \\
\text { in form of clinoforms } \\
D_{\mathbf{x}}\end{array}$ & $\begin{array}{l}\text { medium- to coarse-grained sands; average } \\
\text { thickness of single sets about } 2-4 \mathrm{~m} \text {, maximum } \\
\text { up to } 10-15 \mathrm{~m} \text {; forest laminae straight to sigmoidal }\end{array}$ & $\begin{array}{l}\text { migration of straight-crested bars or progradation } \\
\text { of a delta slope; high-energy shallow-water } \\
\text { environment }\end{array}$ \\
\hline & $\begin{array}{l}\text { trough cross-stratification } \\
\qquad \mathrm{D}_{\mathbf{t}} \\
\end{array}$ & $\begin{array}{l}\text { medium- to coarse-grained sands; } \\
\text { set thickness from } 10 \text { to } 50 \mathrm{~cm}\end{array}$ & $\begin{array}{l}\text { migration of curved-crested ripples; high-energy } \\
\text { shallow-water environment }\end{array}$ \\
\hline & $\begin{array}{l}\text { ripple cross-lamination } \\
\qquad \mathrm{D}_{\mathbf{r}}\end{array}$ & $\begin{array}{c}\text { fine-grained sands; heights of individual ripples range } \\
\text { between } 2 \text { and } 10 \mathrm{~cm} \text {; dominant asymmetrical } \\
\text { and climbing (ripple laminae-in-phase and ripple } \\
\text { laminae-in-drift) ripples, occasionally wavy } \\
\text { and flaser lamination }\end{array}$ & $\begin{array}{l}\text { migration of wave and wave-formed current } \\
\text { ripples; shallow-water environment, } \\
\text { (?)up to intertidal }\end{array}$ \\
\hline & $\begin{array}{l}\text { plane bedding } \\
\mathrm{D}_{\mathbf{p}}\end{array}$ & various sands; thickness of sets rarely exceeds $10 \mathrm{~cm}$ & $\begin{array}{l}\text { lower- or upper-stage plane beds; } \\
\text { low- to high-energy shallow-water environment }\end{array}$ \\
\hline & $\begin{array}{l}\text { large-scale scours } \\
\qquad \mathrm{D}_{\mathbf{s}}\end{array}$ & $\begin{array}{l}\text { large elongated scours filled with fine-grained, } \\
\text { well-sorted sands; depth up to } 10 \mathrm{~m} \text {, widths range up } \\
\text { to } 20 \mathrm{~m} \text {; concave sharp and erosional bottom surface; } \\
\text { basal part massive, top parts with traces of lamination } \\
\text { and numerous folds and diapirs }\end{array}$ & $\begin{array}{l}\text { grain flow in the form of underwater slump-scours; } \\
\text { sediment movement caused by overloading of } \\
\text { slope, rapid drawdown and destruction of frontal } \\
\text { part of a delta body, and/or by seismic shock }\end{array}$ \\
\hline & $\begin{array}{l}\text { channel-like fills } \\
\qquad \mathrm{D}_{\mathrm{ch}}\end{array}$ & $\begin{array}{l}\text { channel-like elongated forms filled with } \\
\text { massive fine- to coarse-grained sands and/or } \\
\text { organodetrital material; sharp concave lower } \\
\text { boundaries, depth up to } 3 \mathrm{~m} \text {, width to } 5 \mathrm{~m}\end{array}$ & storm surge channels, locally filled by lag deposits \\
\hline \multirow[b]{2}{*}{ 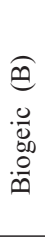 } & $\begin{array}{l}\text { individual burrows } \\
\qquad \mathrm{B}_{\mathbf{b}}\end{array}$ & \multicolumn{2}{|c|}{$\begin{array}{l}\text { syn- or post-depositional activity of shrimps (Callianassa) or crabs (Ocypode), } \\
\text { as well as undetermined sea anemones, bivalves and holothurians }\end{array}$} \\
\hline & $\begin{array}{l}\text { maze of "burrow-ghosts" } \\
\text { of various size, } \\
\text { totally blurring primary } \\
\text { depositional structures } \\
\mathrm{B}_{\mathrm{m}}\end{array}$ & \multicolumn{2}{|c|}{$\begin{array}{l}\text { total destruction of depositional structures, formed by long-terme activity } \\
\text { of abundant bottom dwellers }\end{array}$} \\
\hline \multirow{4}{*}{ 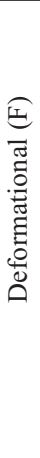 } & $\begin{array}{l}\text { slump (fold and diapir) } \\
\text { structures } \\
\mathrm{F}_{\mathrm{f}} \\
\end{array}$ & $\begin{array}{c}\text { highest parts of scour infills, vertical } \\
\text { or overturned anticlines and synclines, } \\
\text { commonly detached, with strongly deformed flexure } \\
\text { zones; up to } 2 \text { m height }\end{array}$ & $\begin{array}{l}\text { caused by collapse of large-scale bars } \\
\text { or delta slopes and/or by seismic shock }\end{array}$ \\
\hline & $\begin{array}{l}\text { convolute bedding } \\
\qquad \mathrm{F}_{\mathrm{c}}\end{array}$ & $\begin{array}{l}\text { small-scale folds underlain or } \\
\text { overlain by non-deformed deposits; deformed layer } \\
\text { thickness up to } 30 \mathrm{~cm} \text {; anticlinal parts } \\
\text { are steep and chevron-like, synclinal } \\
\text { are flat }\end{array}$ & $\begin{array}{l}\text { result of reversed density gradient or sediment } \\
\text { liquefaction; caused by overburden of overlying } \\
\text { deposits, seismic shock and/or movement } \\
\text { of liquefied sediment }\end{array}$ \\
\hline & $\begin{array}{l}\text { pseudonodule structures } \\
\qquad \mathrm{F}_{\mathbf{p}}\end{array}$ & $\begin{array}{l}\text { disturbed bedding in form of ovate or spherical } \\
\text { masses surrounded by massive sands }\end{array}$ & $\begin{array}{l}\text { fluid-loss structures, produced by escaping water, } \\
\text { breaking upwards through primary lamination; } \\
\text { caused by gravity mass movement or deformational } \\
\text { shear of currents }\end{array}$ \\
\hline & $\begin{array}{l}\text { structureless } \\
\mathrm{F}_{\mathrm{s}} \\
\end{array}$ & $\begin{array}{l}\text { sands completely devoid of any sedimentary } \\
\text { structures; bodies up to } 15 \mathrm{~m} \text { thick }\end{array}$ & $\begin{array}{l}\text { homogenisation caused by rapid sedimentation, } \\
\text { total bioturbation, redeposition, and/or liquefaction }\end{array}$ \\
\hline
\end{tabular}

Creusia at Stratyn, both as yet unknown from the Ukrainian part of the Fore-Carpathian Basin, and discussed below.

The bryozoans, apart from being present as fine detritus in many layers (e.g., at Romaniv), are represented also by well-preserved, large colonies (at Khorosno, Pukiv); they are presently being studied by Dr. Kamil Zágoršek, of the National Museum at Prague, Czech Republic.

Shark teeth are common, occurring singly in some sections (e.g., at Gleboviti, Khorosno, Pidiarkiv, Berezhany) and reported earlier (Łomnicki, 1897; Kudrin, 1957b). At Khorosno, there are associated toothplates of the rays (Batoidei) Myliobatis, unknown formerly from the Ukrainian part of the Fore-Carpathian Basin.

\section{ECO-TAPHONOMY OF FOSSILS}

As regards the eco-taphonomy of the Mykolaiv Sands biota, their mode of preservation is diverse. Biota are excep- tionally preserved, in life position, as in the stumps of taxodiacean conifers at Gleboviti, and some animals. The latter include detritus-armoured tubes of Diopatra-type polychaetes, and sandy moulds of the bivalve Panopea, the environmental significance of which is discussed below.

Except for these cases, all animal fossils were hydrodynamically reworked, to be either dispersed randomly in a sand layer, or accumulating in certain layers. In the case of echinoderms, studied separately (Radwański and Wysocka, 2001), it is even possible to recognize whether entombment took place in life (in vivo), or after death (post mortem).

In the case of the starfish Astropecten forbesi Heller, 1858, their preservation as complete skeletons (Fig. 5A, B), locally fragmented (at Gleboviti, Yasnyska, Khorosno), indicates rapid burial of freshly dead specimens. Some such specimens, within storm layers (tempestites) at Gleboviti, appear in a position typical of mortal cramp (see Fig. 5A) which suggests their burial while still alive (that is, in vivo). The same is inferred for the endobenthic echinoids Echinocardium leopolitanum 

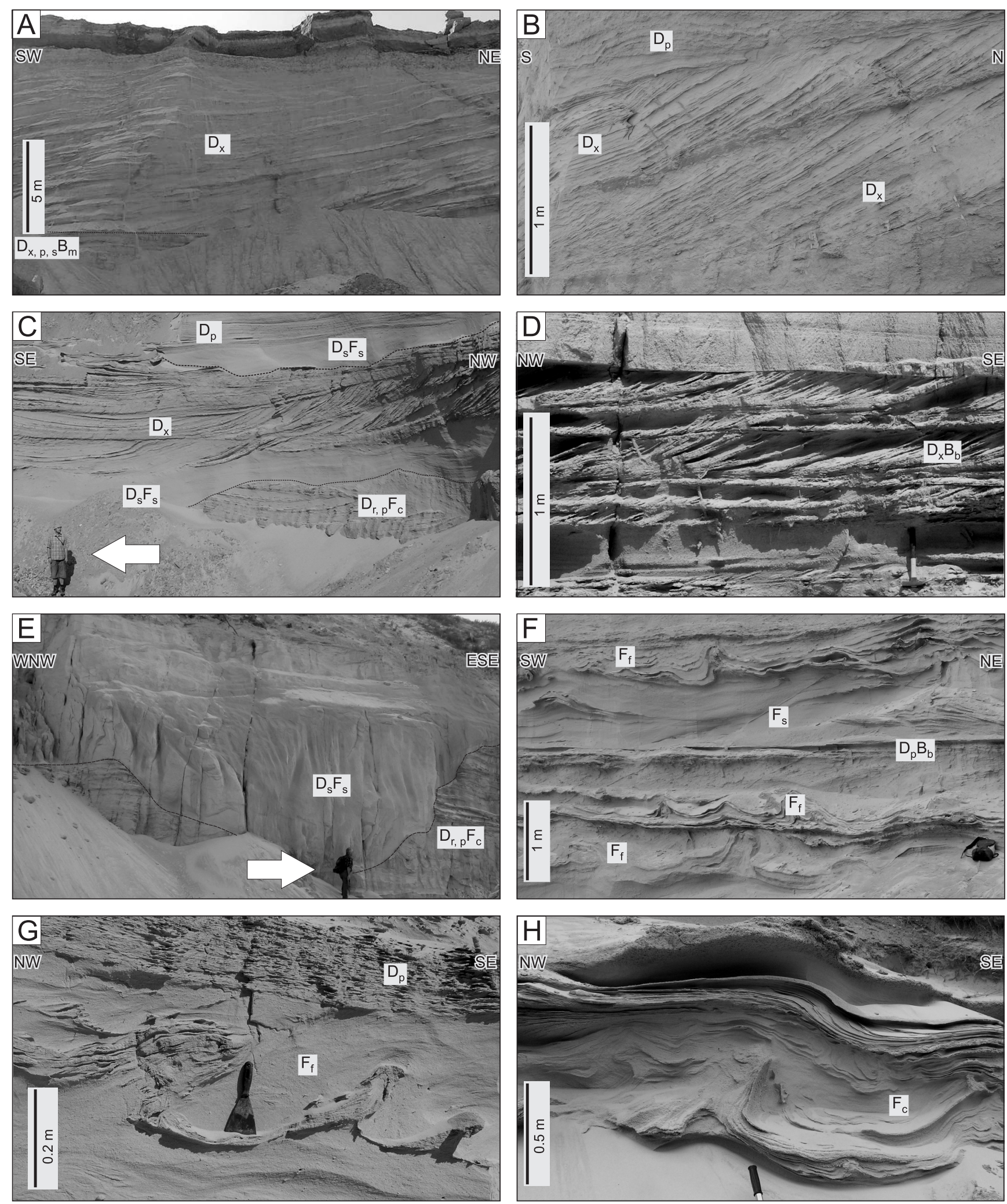

Fig. 4. Sedimentary structures of Mykolaiv Sands

A - progradational set of large-scale tabular cross-stratification, downlapping on plane-stratified sands (Sykhiv); B - cosets of tabular cross-stratification (Khorosno); C - channel-like in fills (base outlined) cut into cosets of tabular and trough cross-stratified sands (Khorosno); $\mathbf{D}$ - cosets of tabular cross-stratification with single Ophiomorpha burrows (Hlukhivets); E - large-scale cross-section of a giant scour filled with structureless sands (Hlukhivets); $\mathbf{F}$ - cosets of synsedimentary deformed layers (Khorosno); G - small-scale fold deformations overlain by non-deformed deposits, to show that south-inclined anticlinal parts are steep whereas synclines are flat (Romaniv); $\mathbf{H}$ - close-up of convolute bedding (Romaniv); for explanations see Table 1 and Figure 8 

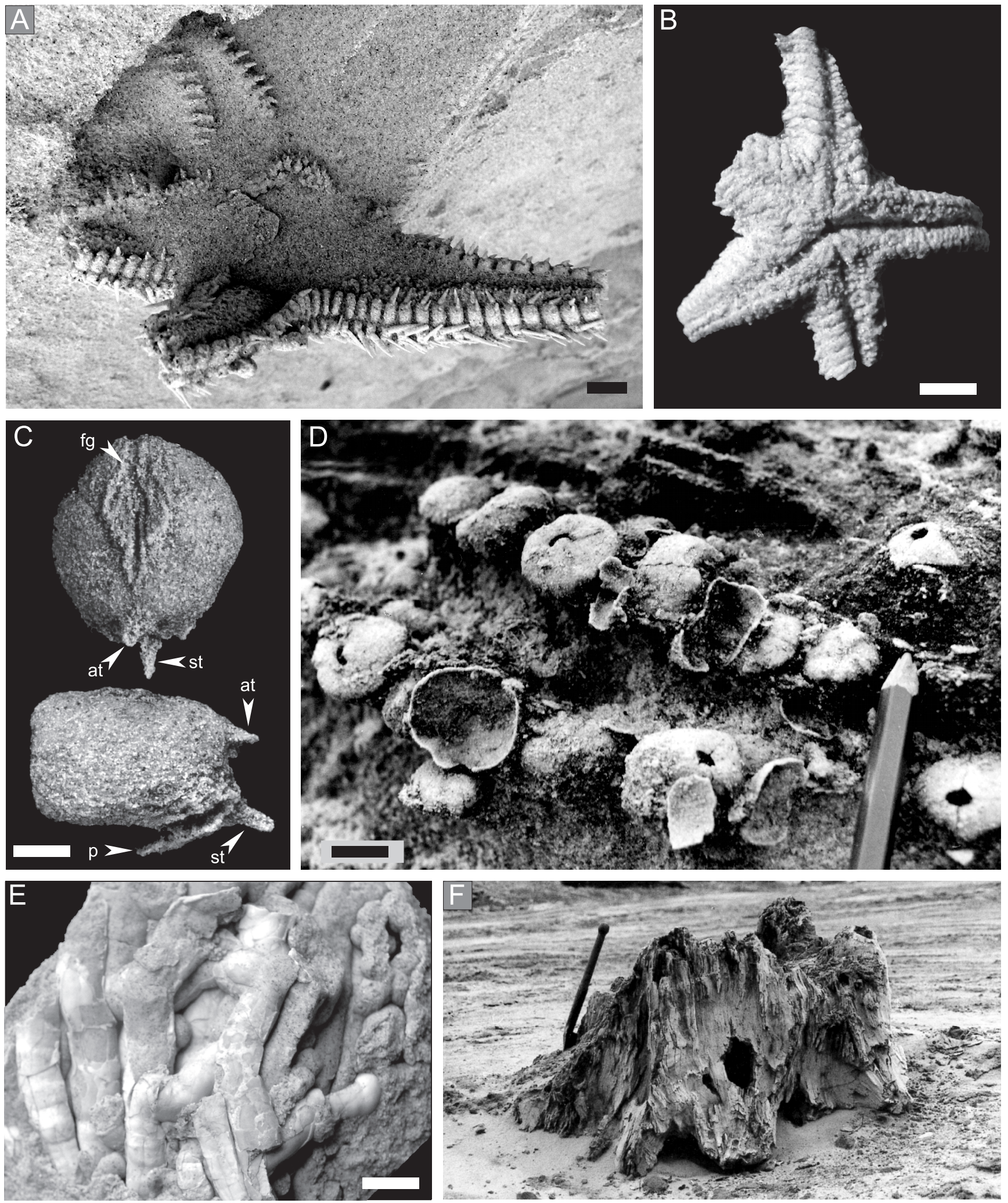

Fig. 5. Eco-taphonomic variants of fossils occurring in the Mykolaiv Sands

A - starfish Astropecten forbesi Heller, 1858, buried in vivo in a storm layer at Gleboviti (field photo); B - another specimen of starfish Astropecten forbesi Heller, 1858 (oral view) from a storm layer at Gleboviti; C - echinoid Echinocardium leopolitanum Radwański and Wysocka, 2001 (top and side views), buried in vivo, with fully preserved spine canopy, to show a spine array: fg - frontal groove terminated with apical tuft spines (folded), at - anal tuft spines, st - subanal tuft spines, p - locomotory spines; storm layer at Gleboviti; D - current-oriented (imbricated), naked tests of Echinocardium leopolitanum Radwański and Wysocka, 2001, in a tabular (diagonal) cross-bedded set at Gleboviti; E - sandy internal moulds (steinkerns) of teredinid bivalves which bored into a timber log (disintegrated), from Romaniv; $\mathbf{F}$ - large, silicified stump of a taxodiacean conifer (field photo) preserved in situ at the base of the Middle Miocene (Badenian) section at Gleboviti; scale bar is $1 \mathrm{~cm}$; shovel on Figure $5 \mathrm{~F}$ is about $0.5 \mathrm{~m}$ 
Radwański and Wysocka, 2001, which are commonly preserved with a complete spine canopy (see Fig. 5C) when exhumed, and re-buried by a storm sand-sheet. In the case of current deposition, the tests are spineless, devoid of canopies, thus having been buried evidently after death and partial decomposition of their skeletons. Such a mode of preservation is typical in planar cross-bedded layers (in sets with straight foreset laminae) where the echinoid tests are usually current-oriented (imbricated, see Fig. 5D).

In terms of environmental significance, the Mykolaiv Sands and in the basal part of the overlying limestones (see Figs. 7 and 8) include fossils which, using uniformitarian criteria, indicate extremely shallow subtidal to intertidal life conditions. At Khorosno, there are vertically preserved tubes, heavily armoured with shell detritus (see Fig. 7B 1 ), comparable to those of the present-day polychaetes of Diopatra type. They reinforce the tubes (see Myers, 1970, fig. 1c; adapted in Fig. $7 \mathrm{~B}_{2}$ herein) to protect them against a "to-and-fro" motion of tidal water and its sediment load (see also Fig. $7 \mathrm{~B}_{3}$ ).

At Gleboviti, the uppermost parts of siphonal tubes of the bivalve genus Stirpulina Stoliczka, 1870, or its congener Clavagella, Lamarck, 1818 are similarly constructed. These funnel-shaped collars (see Fig. $7 \mathrm{~A}_{1}$ ), built of calcite, are the only preserved fragments of these bivalves, the aragonite-built remaining part of the tubes and the whole shell being dissolved (Bałuk and Radwański, 1984; Figs. 2 and $7 \mathrm{~A}_{2}, \mathrm{~A}_{3}$ herein; Dulai, 1996).

Similar life requirements are also inferred from the clusters of endobenthic bivalves Panopea (see Fig. 7C), preserved as sandy internal moulds of originally aragonitic shells. Their moulds, mass-occurring locally (e.g., at Romaniv, see Fig. 8; individually at Stratyn, see Fig. 7D), all stand vertically in life position, as do living bivalves stretching out their siphons, through a sandy layer, to a temporary Middle Miocene (Badenian) sediment/water interface.

Uniformitarian criteria may, in the Mykolaiv Sands, also be applied to the cirripede genus Creusia Leach, 1817, the present-day representatives of which live as obligate as endo-commensals of scleractinian corals in extremely shallow-marine habitats (see Boucot, 1990, pp. 15-18). Their calcitic shells, as those from Stratyn (Fig. 6B,$B_{2}$ ) we infer as derived from aragonite, scleractinian colonies, via surf action or otherwise hydrodynamically rather then by chemical filtering [The latter was not a case in the Creusia shells studied, as they are contained in a sand matrix (see Fig. $6 \mathrm{~B}_{1}, \mathrm{~B}_{2}$ ), instead of resting in a hollow left after a dissolved scleractinian colony]. There are bathymetric (shallowest to intertidal) and climatic (sub- to tropical) requirements in extant species of this genus.

This facies- or substrate-restricted biota may indicate either an in situ preservation to form an autochthonous community/assemblage (e.g., taxodiacean stumps in sands; Diopatra and Panopea from overlying beds, see below), or the fossils (fragmentary like Stirpulina, complete as Creusia) more commonly belong to allochthonous assemblages which dominate in the sections studied. Those, being preserved near the original life habitats, are classified as parautochthonous assemblages.

All allochthonous assemblages studied have variable content and diverse frequency. All include representatives of diverse ecological groups, ranging from endo- and epibenthic, sessile and vagile, nektic (sharks) to pelagic (driftwood, ?succinite). Apart from the plants and shark teeth, all invertebrate fossils contained are either represented by their complete shells/tests (such as echinoids with their spine canopy, starfish skeletons, the cirripede Creusia), or by disintegrated/disseminated parts/ossicles (such as isolated echinoid spines and plastrons, starfish ossicles, small scallop valves). Of the latter group, there also occur locally (at Khorosno), but quite common there, disseminated plates of the stalked cirripede genus Scalpellum Leach, 1817, unknown as yet from the Ukrainian part of the Fore-Carpathian Basin; the collected plates (see Fig. $6 \mathrm{~A}_{1}, \mathrm{~A}_{2}$ ) resemble Scalpellum burdigalense Des Moulins, 1875 (see Withers, 1953, fig. 95).

\section{THE BURROWS}

Diverse burrows are typical features of all sections studied. The most common are "classical" Ophiomorpha nodosa Lundgren, 1891, ascribed for over half a century (Weimer and Hoyt, 1964) to shrimps of the genus Callianassa Leach, 1814. Their present-day producer C. major Say, 1818, is nowadays classified to the genus Callichurus (see Goldring et al., 2004). These burrows, either very friable, or more less firmly cemented, occur singly in most of the layers throughout the whole sequence (see Fig. 8), except in some thick-bedded ones (cross-bedded, or homogenous). In some horizons they are abundant, crowded together densely in vertical position (e.g., at Stratyn).

The less common burrows are these of the Ghost Crab Ocypode, usually associated with those of Callichurus, and frequent in some horizons, mostly at Stratyn from where they have been described (Radwański et al., 2012).

Locally abundant, and mass-aggregated in residual lags, are burrows of echinoids Echinocardium leopolitanum (e.g., at Gleboviti, Yasnyska), which have also been studied separately (Radwański and Wysocka, 2001, pl. 8, figs. 1, 2).

There are large, individual multiple-funnel shaped burrows, 20-30 centimetres deep, which are ascribed to the activity of sea anemones (see Wysocka, 2002, p. 553, pl. 9, figs. 1, 2 and 4; Radwański et al., 2012).

There are also undetermined pocket-shaped burrows comparable to these of present-day holothurians of Thyone-type (cf. Howard, 1968, fig. 2), and burrows which may be ascribed to the activity of polychaetes and bivalves other than those discussed above.

\section{TYPICAL SECTIONS}

In Opole Minor, several tens of exposures of the Mykolaiv Sands show the variability of sedimentary structures and biotic content. End members are shown on selected sections (Fig. 8), one of which (Gleboviti) has previously been studied systematically.

Romaniv, an abandoned local sand-pit (previously unreported), lies along a stream escarpment, exposing a tripartite section about $15 \mathrm{~m}$ thick. It starts with fine-grained, strongly deformed, and occasionally structureless sands, where 

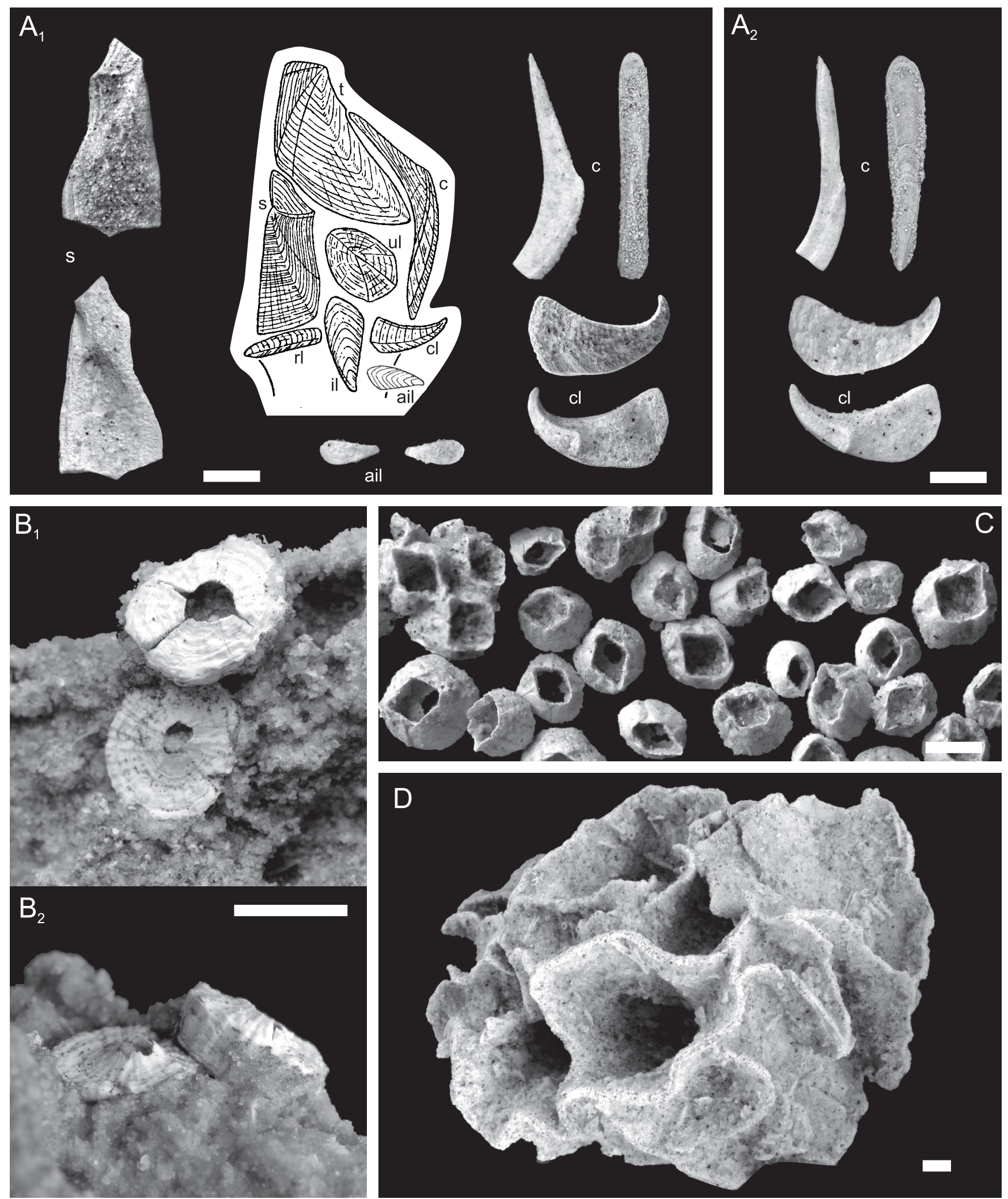

Fig. 6. Allochthonous assemblages of fossils at Khorosno and Stratyn

A - stalked cirripede Scalpellum burdigalense Des Moulins, 1875: A - restored array (right side) of plates armouring the capitulum, combined from des Moulins (1875, pl. 2) and Withers (1953, fig. 95), and isolated plates from Khorosno: $\mathrm{s}-$ left scutum (outer and inner views), $\mathrm{c}$ - carina (side and top views), $\mathrm{cl}$ - right carinolatus (outer and inner views), ail - additional infralatus (outer and inner views), $\mathrm{t}$ - tevgum, ul - upper latus, il - intramedian latus, $\mathrm{rl}$ - rostral latus; $\mathrm{A}_{2}$ - carina and right carinolatus of other specimens, isolated plates; $\mathbf{B}_{1}-\mathbf{B}_{2}-$ two specimens of the cirripede Creusia sp., in top $\left(\mathrm{B}_{1}\right)$ and side $\left(\mathrm{B}_{2}\right)$ views, from Stratyn; $\mathbf{C}$ - isolated (substrate detached) crowns of the cirripede Balanus sp., from Khorosno; $\mathbf{D}$ - complete bryozoan colony of ? Sertella (?Retepora) type, from Khorosno; scale bar is $0.5 \mathrm{~cm}$ 

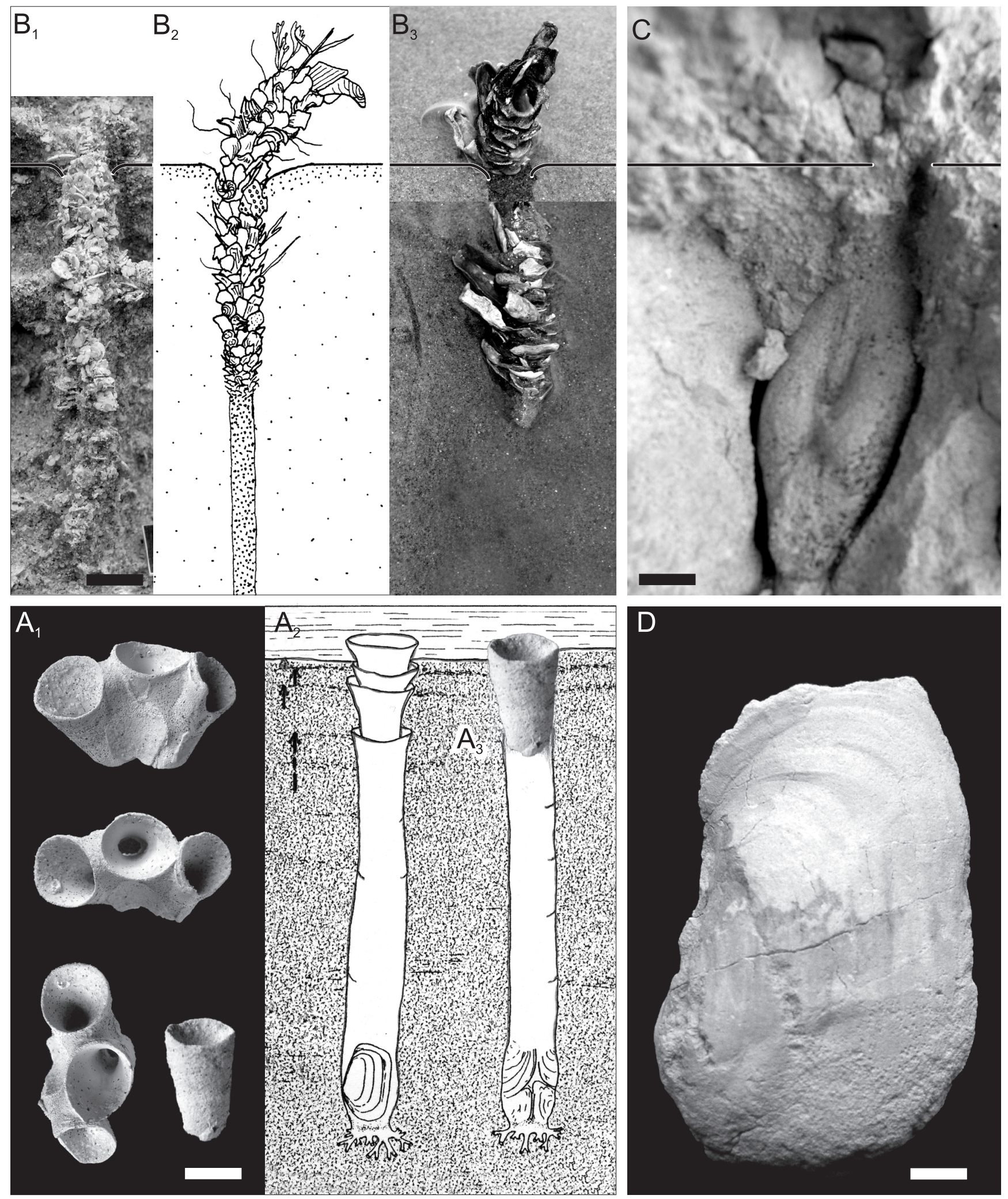

Fig. 7. Intertidal fossils of the Mykolaiv Sands and overlying limestones

$\mathbf{A}_{1}$ - funnel-shaped collars (a group of three, and one isolated) of siphonal tubes of the bivalve Stirpulina from Gleboviti; $\mathbf{A}_{2}, \mathbf{A}_{3}-$ scheme of the shell structure in Stirpulina bacillum (Brocchi, 1814) from the Korytnica Basin in Poland (adapted from Bałuk and Radwański, 1984, fig. 2); in specimen from $\mathrm{A}_{3}$ an isolated collar $\left(\mathrm{A}_{1}\right)$ is mounted, to show the whole shell construction; $\mathbf{B}_{1}$ - tube of a polychaete of Diopatra-type from Khorosno; $\mathbf{B}_{2}-$ scheme of tube of the present-day Diopatra cuprea (Bosc, 1803) from the Georgia coast, U.S.A. (adapted from Myers, 1970, fig. 1a); $\mathbf{B}_{3}-$ similar tube construction from the present-day intertidal Gomso Bay, western coast of South Korea (photo by A. Wysocka, 2006); C - Panopea internal mould (steinkern) in life position of the bivalve at Romaniv, field photo; $\mathbf{D}$ - isolated specimen (internal mould) of Panopea from Stratyn; in Figure $7 \mathrm{~A}_{2}-\mathrm{A}_{3}, \mathrm{~B}_{1}-\mathrm{B}_{3}$ and $\mathrm{C}$ indicated is a temporary sediment/water interface; scale bar is $1 \mathrm{~cm}$ 
small-scale south-inclined folds predominate. Anticlinal parts of these folds are steeper, than synclinal ones, and they are overlain by non-deformed deposits. In the upper part, a largescale, low-angle cross-bedded set with abundant Ophiomorpha burrows is present. Above, there are planar cross-bedded biocalcarenites. The section is terminated by marly limestones, the lowermost layer of which has common Panopea preserved as sandy shell moulds; these stretch out with their gaping valves upwards, in life position, to represent an autochthonous community or "frozen behaviour" (sensu Boucot, 1990).

The biotic content of allochthonous assemblages, apart from the bryozoan detritus, is very scanty, containing the large foraminifer Heterostegina and the small echinoid Echinocyamus.

Stradch, an abandoned sand-pit, displays large channel-like infills and deformational sedimentary structures that recur several times in the section. The channel-like infills, in most cases, are structureless in their lower parts (but contain residual lags) and strongly deformed in their upper parts. Moreover, the largest ones are associated with deformations of the surrounding sand, ranging from small-scale convolute bedding to diapirs 2 metres high (see Wysocka, 2002, pl. 7, fig. 1) likely generated by overload of channel infills upon cohesive unstable sands. The $20 \mathrm{~m}$ thick sequence is directly overlain, with a sharp boundary, by the Ratyn Limestones.

Biotic content comprises only large boulders of silicified wood seemingly in residual lags of the channel-like infills.

The section is interpreted as representing a deeper offshore setting with shore-faced sand-masses repeatedly slumped due to gradient increases and/or a seismic triggering.

Sykhiv, a newly re-opened sand-pit (see Wysocka, 2002), displays a bipartite sequence more than $20 \mathrm{~m}$ thick (cf. Teisseyre, 1938, p. 127), the lower part of which is built of tabular cosets of planar bedding, with subordinate cross-bedding, all having been almost completely blurred by intense bioturbation. The upper part is a very large cross-stratified set, unfossiliferous, and directed towards the south-west (Fig. 4A). Sporadically, channel-like scours filled with structureless sands appear in the lower unit containing numerous echinoid burrows. The equence is overlain by marly red-algal (lithothamnian) limestones.

The section is interpreted as a result of rapid deposition, either of an extremely large (10 metres high), cross-stratified sand bar (presumably of storm origin), or progradation of a delta slope, which developed upon a monotonous planar-bedded rhythmic series of interbedded tabular and cross-bedded sets.

Gleboviti, a partly abandoned sand-pit, where exploitation reached nearly to the Upper Cretaceous basement upon which the silicified stumps of taxodiacean conifers are rooted (Radwański and Wysocka, 2001; Wysocka, 2002). The section comprises a $12 \mathrm{~m}$ thick sequence built of fine-grained sand units with various depositional and biogenic structures. The lower part is dominated by tabular cross-stratified sets, the middle one by cross-sets strongly bioturbated by the echinoid Echinocardium leopolitanum. Above them, a large-scale tabular cross-stratified set occurs. The sequence is terminated by tabular cross-sets with single burrows Ophiomorpha, and overlain by sandy red-algal (lithothamnian) limestones.
The biotic content is dominated by the ubiquitous echinoid Echinocardium leopolitanum Radwański and Wysocka, 2001, locally mass-aggregated, and preserved either with spine canopies or as naked tests. Spine-bearing examples present in storm layers, are associated with the starfish Astropecten forbesi Heller, 1858, preserved as complete skeletons. Naked tests are contained in cross-sets, and are commonly imbricated. Other fossils are extremely rare, and include tube collars of the bivalve Stirpulina and shark teeth (Odontaspis, Isurus).

The section is interpreted as a facies succession of facies that ranges from an inferred coastal swamp undergoing transgression, to a distal sublittoral and deeper offshore setting, within a sequence of the reduced thickness ( $c f$. Fig. 8). The mass-occurrence of Echinocardium leopolitanum suggests its provenance (as for the co-associated Stirpulina) from nearby intertidal settings, as with present-day relatives (see Radwański and Wysocka, 2001, p. 307; and Higgins, 1974, pl. 7b).

Stratyn, an abandoned sand-pit, has its lower part covered by quarry dumps. The accessible part of the section, over 10 metres thick shows ubiquitous and diverse burrows, of which those of the Ghost Crab Ocypode have been studied separately (Radwański et al., 2012), and is overlain by marly biocalcarenites. The lower part of the section is locally uncovered, to show homogeneous sand, with an estimated thickness of some 20-30 metres.

The scarce biota is represented by small invertebrates, of which the rarest, but facies indicative, are the cirripedes Creusia (the only examples in the Mykolaiv Sands). More frequent are poorly preserved inarticulate brachiopods Crania (? or Craniscus), the echinoids Echinocyamus and Spatangus, isolated ossicles of the starfish Astropecten, small scallops and/or oyster detritus, as well as scattered large foraminifers Heterostegina.

The section is interpreted ( $c f$. Radwański et al., 2012) as reflecting progradation, through shallow subtidal to intertidal. Extremely shallow depths are indicated both by the burrows' producer, the Ghost Crab Ocypode, as well as by the cirripedes and brachiopods of likely parautochthonous nature. Their, remains in the limited depth of water, were deposited very near the living communities.

Khorosno, an intensely exploited large sand-pit (previously unreported) shows a section about $20 \mathrm{~m}$ thick which is composed of two parts. The lower, about $10 \mathrm{~m}$ thick, is built of fine-grained quartz sands, with significant admixture of calcareous mud and clay minerals, showing channel-like scours (Fig. 4C) cut into cosets of tabular and trough cross-stratified sands (Fig. 4B, C). The basal parts of the scour infills are structureless, whereas the top parts are characterized by traces of lamination and numerous fold and diapir deformations (Fig. 4F). The same pattern takes place repeatedly, and particular scours and/or cosets of deformed sandy layers are vertically stacked. The deformations show south wards inclination of overturned anticlines, dying out upwards. These strata are covered by slightly deformed laminated sands with some clay (illlite and/or folidoide). All are incised by a very large channel-like infill, capped by planar-bedded shallower sands with ubiquitous Ophiomorpha burrows. 


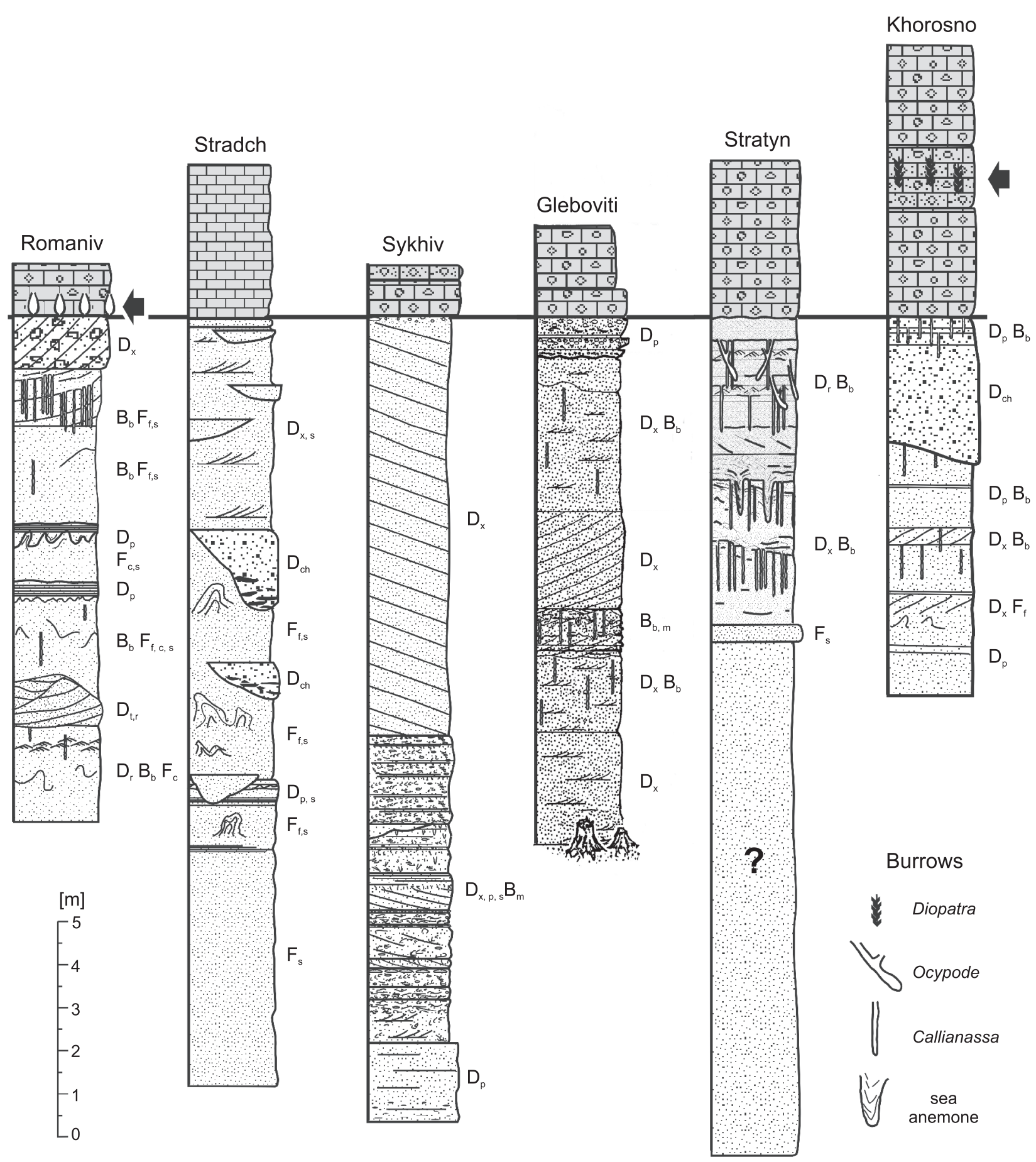

Fig. 8. Selected sections of the Mykolaiv Sands, to exemplify the diversity of sand bodies yielding variable sedimentary and biogenic structures, and their vertical succession

For other explanation see Table 1 and Figure 4; locations of intertidal biota in overlying limestones are arrowed

The biotic content is the most diverse among the sections studied. Contained mostly in cross-sets, it is composed of red-algal and fine bryozoan detritus, in which larger bryozoan colonies are common (Fig. 6D), associated with numerous large foraminifers (Amphistegina), empty crowns of the small acorn barnacle Balanus (Fig. 6C) and disseminated plates of the stalked barnacle Scalpellum (Fig. 6A $\mathrm{A}_{1}, \mathrm{~A}_{2}$ ), as well as echinoderm clasts. The latter, taxonomically filtered (sensu Nebelsick, 1995), contain marginal ossicles of the starfish Astropecten, variably damaged tests of the echinoid Hemipatagus ocellatus (Defrance, 1827) and their fragments, the same as broken fragments of Echinocardium leopolitanum and of large Clypeaster sp. and Conolampas sp. The number of echinoid species totals twelve. 


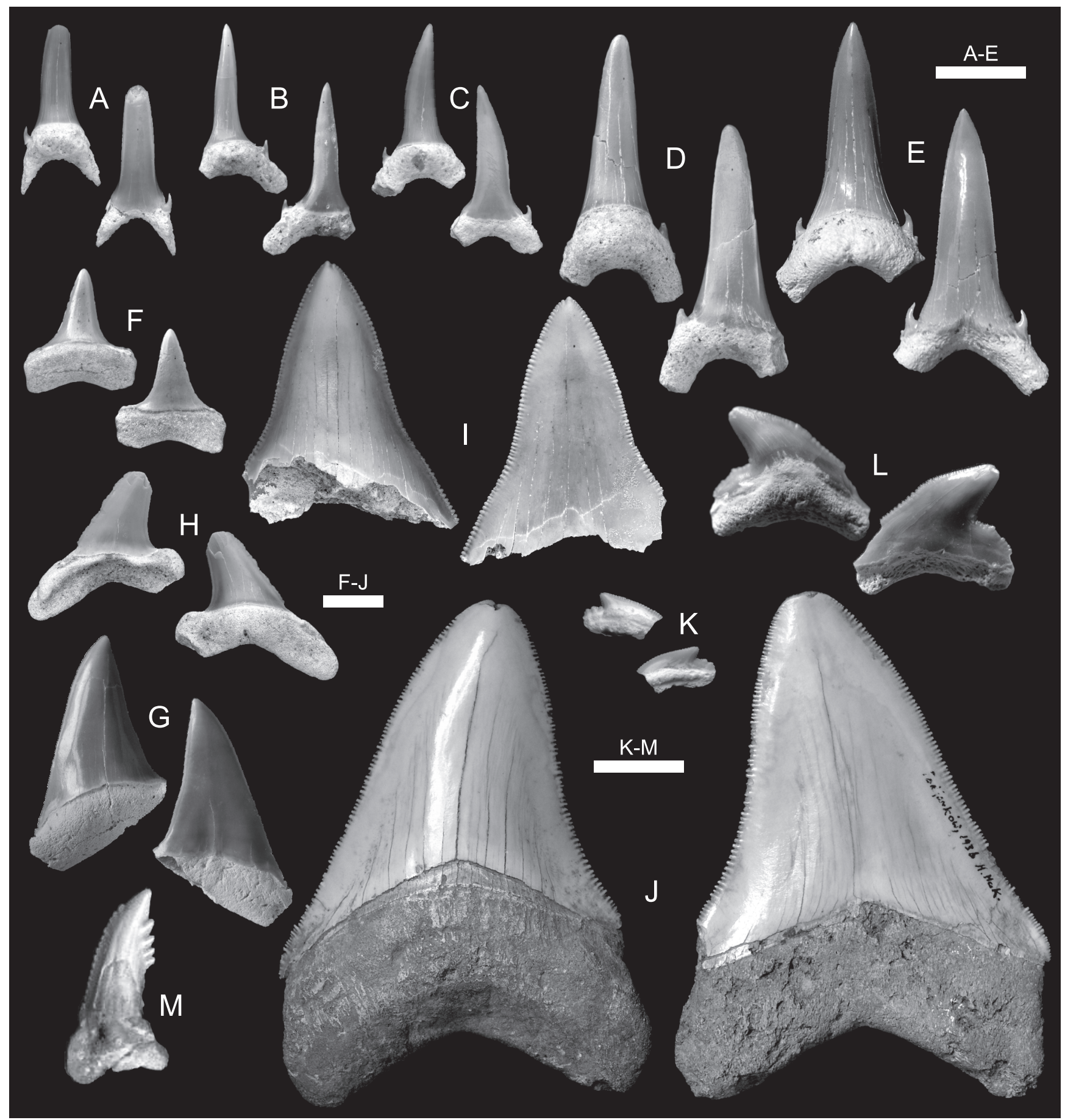

Fig. 9. Shark teeth from the Mykolaiv Sands; inner (lingual) and outer (labial) views

A-C - Odontaspis acutissima Agassiz, 1844, from Khorosno; D, E - Odontaspis cuspidata Agassiz, 1844, from Gleboviti; F, G - Isurus hastalis (Agassiz, 1843): F - lower posterior tooth (coll. M. Bieńkowska, 2006), G - upper anterior tooth, both from Gleboviti; H - Isurus retroflexus (Agassiz, 1843), lateral tooth from Khorosno; I, J - Carcharodon megalodon Agassiz, 1843: I - from Khorosno, J - from Pidiarkiv (coll. Makowski, 1936); K, L Galeocerdo aduncus Agassiz, 1843: K - posterior tooth, L - lateral tooth, both from Khorosno; M - Hemipristis serra Agassiz, 1843: right lower lateral tooth in inner (lingual) view, from Berezhany (collection of O. Stalennyi, Ternopil); scale bar is $1 \mathrm{~cm}$

The nektic elements are represented by the very common small, and rarely by large, scallops Macrochlamis nodosiformis (de Serres in Pusch, 1837), as well as by shark teeth (Odontaspis, Galeocerdo, Megalodon) and toothplates of rays (Myliobatis).
The section is interpreted as a result of accumulation, mostly by bottom currents, of diverse faunal remains which are otherwise under-represented or absent in other sections studied. The current-sorted remains form typical allochthonous assemblages. Their members show the diversity of the biotic communities and their life conditions over an extent of sea floor rang- 
ing from eulittoral habitats (Balanus, Scalpellum), sublittoral phothic zone of seagrass beds (bryozoans, Amphistegina, Echinocyamus, ?Clypeaster, ?Conolampas), to various offshore sandy bottoms (Astropecten, abundant but dwarfish echinoids Psammechinus), with common nektic elements (sharks and rays). Some of these forms (the cirripede Scalpellum, the ray Myliobatis) are new for the Ukrainian part of the Fore-Carpathian Basin.

\section{A NOTE ON SHARKS}

The Mykolaiv Sands contain common and diverse shark remains. Five genera have been recognized (see Fig. 9A-M): Odontaspis, Isurus (Oxyrhina), Galeocerdo, Carcharodon, and Hemipristis ${ }^{1}$. Typically, their extant representatives are large, measuring up to 3-5 metres (Carcharodon even more) in length. This is apparently puzzling, if we consider the environmental conditions during deposition of the Mykolaiv Sands, suggesting a lack of space and of potential food for such large sharks. The three of the indicated genera, the Mako Shark (Isurus), the Tiger Shark (Galeocerdo), and the White Shark (Carcharodon), are known today for their extreme ferocity (see Budker, 1971, p. 119). Throughout the whole region of the Mykolaiv Sands, no satisfactory food source for them has been found. Of potential prey such as teleost fish and/or smaller marine mammals, no remains have as yet been found; dolphins (noted by Łomnicki, 1897 and Kudrin, 1957a, b) and porpoises (Kudrin and Tatarinov, 1965), are represented by single occurrences of bones/vertebrae.

The space was limited by the formation of diverse sand bodies, some rising to sea level. Such shallows/shoals could be favourable only for the smallest, the Sand Shark (Odontaspis), that today ventures into shallow offshore sand regions. This shark appears to be the commonest (see Fig. 9A-E) throughout the Mykolaiv Sands.

The rarest of the sharks recognized is the Snaggletooth Shark (Hemipristis), present-day representatives of which live in coastal waters of the Indian Ocean (Cappetta, 1987, p. 119); its teeth (see Fig. 9M) have not formerly been reported from the Ukrainian part of the Fore-Carpathian Basin.

The sharks in these deposits may simply have starved when prowling/wandering amidst the shoals and shallows of the Mykolaiv Sands, perhaps indicative of the open seaways through which they could spread from other Paratethyan basins, from where they are commonly known (see Radwański, 1965; Schultz, 1998, pl. 55), as in other shallow marine Miocene basins in Europe (see e.g., Leriche, 1957). This shark assemblage differs distinctly from those (which is composed of such genera as Heptranchias, ?Mitsukurina, Alopias, and Cetorhinus) typical of the open-oceanic (Tethyan) realm pre- vailing earlier in the Oligocene of the Carpathian Basin (see Bieńkowska-Wasiluk and Radwański, 2009).

\section{REGIONAL INTERPRETATION}

In general, the Mykolaiv Sands studied allow to understand their body as representing an extensive regional sandbody accretion prism which, in the Ukrainian part of the Fore-Carpathian Basin, carpeted the pre-Miocene topography at the margin of the East-European Platform, though not reaching the zone that was gradually downthrown south-westwards towards the Carpathian Foredeep. Such a tectonic setting is thus identical to that recognized in the Holy Cross Mountains (see Radwański, 1973, fig. 13) and Lublin Upland (see Wysocka, 2002, fig. 11) in the Polish part of the Fore-Carpathian Basin. This unit, though, covers a much larger extent and has a more complex anatomy, governed by both the pre-Miocene topography of the region and the dynamic conditions of the Middle Miocene (Badenian) transgression.

The sand supply is inferred to have been from Paleogene erosion of the East-European hinterland of Podolia and Volhynia (Radwański et al., 2012). The mode of its delivery is as yet unknown: neither fluviatile or aeolian transport, nor deltaic input has been recognized in the sequences studied. All facies studied (see Table 1) are typical of very shallow-marine, high-energy bottom conditions.

At the first stage of transgression, sand was swept into topographic depressions of Paleogene age, with an early suggestion (Teisseyre, 1938), of current deposition along the leesides of bottom hummocks of the Cretaceous basement, remaining plausible. An uneven bottom morphology, at this stage, controlled current directions (Wysocka, 2002) until the this topography was smoothed by sedimentation to form an extensive offshore zone. As long as topography remained, slumping and liquefaction were locally important, to produce homogenized sand bodies up to 15 metres thick. Then, the sand bodies were influenced by storms agents (with scouring and residual lags), or by waves and currents, to produce sand bars of variable heights (up to 4, rarely to 10-15 metres). Amongst these the planar to small-scale cross-stratified sequences suggest meander processes, some reminiscent of tidal creeks (see Wysocka, 2002, figs. 10,11). As there is no evidence of tidal action in the Fore-Carpathian Basin, such conditions are thought to have involved extreme offshore winds (a "pseudotidal effect") or regional lowstands. The latter could have resulted from tectonic uplift of the shore and adjacent hinterland, or from compensation of subsidence by terrestrial increasing supply (significant evaporation is precluded, based on the faunal evidences).

Within this physical background, the biosedimentary structures of the Mykolaiv Sands are important. The best defined

\footnotetext{
${ }^{1}$ These classical genus names (see Budker, 1971; Cappetta, 1987) are used herein to be accessible for the readers less advanced in the widespreading modern "jungle" of shark taxonomy
} 
burrows, those produced by shrimps (Callianassa vel Callichurus) and crabs (Ocypode), yield environmental information consistent with the sedimentary data. These burrows indicate extremely shallow-marine high-energy habitats, under subtropical to tropical climatic conditions (see Goldring et al., 2004; Radwański et al., 2012). Those of the Ghost Crab Ocypode document local emergence (e.g., at Stratyn, see Radwański et al., 2012).

Under these conditions, the ubiquitous sessile and vagile benthos flourished, with biodiversity greater than in the Polish part of the Fore-Carpathian Basin. In both parts, Polish and Ukrainian, the total marine assemblages, from various facies, indicate an influx of tropical/subtropical elements of the IndoWest Pacific Bioprovince (Bałuk and Radwański, 1977; Radwańska, 1992; Radwański et al., 2006). Faunal elements new to the Ukrainian part of the Fore-Carpathian Basin include the cirripede Creusia, the burrowing crab Ocypode, and the shark Hemipristis. The biotic conditions illustrate well the global Langhian Climatic Optimum of the earliest Middle Miocene, prevaling during the early Badenian (see Harzhauser et al., 2003, p. 336; Kroh, 2007).

Tropical/subtropical climatic conditions prevailed across the whole Fore-Carpathian Basin, regardless of its northernmost location among the network of Paratethyan basins. These conditions were thus evidently warmer than those suggested by Kroh (2007, p. 195), though a wider extent of the tropical zone in early Middle Miocene time was also considered by that author (Kroh, 2007, p. 169).

The variable bottom morphology in the studied part of the Fore-Carpathian Basin created a number of more or less specialized communities (some monospecific), which were intermittently destroyed in high-energy events, such as storms, strong waves and current scouring. Most of the faunal assemblages preserved were swept out of their life positions, and deposited at a shorter (parautochthonous assemblages) or greater (allochthonous assemblages) distances from them. Deeper erosion could locally produce residual lags of early cemented echinoid burrows (of Echinocardium at Gleboviti; see Radwański and Wysocka, 2001, p. 309 and pl. 8, figs. 1, 2). The rare autochthonous assemblages, apart from the taxodiacean stumps, preserved in situ in their life position, include the Ocypode burrows indicative of sub- to intertidal conditions. The latter suggest a diminishing water column at the final developmental stage of the Mykolaiv Sands.

Overlying the Mykolaiv Sands are (except for the local Ratyn Limestones) the lithothamnian limestones of the MidLithothamnian Horizon, the regional significance of which remains unclear. Their variable structure (sandy or clay intercalations) and thickness (from several centimetres to several metres, locally up to $20 \mathrm{~m}$; see Lomnicki, 1897; Teisseyre, 1938; Pazdro, 1953), as well as a total absence of higher-energy dynamic events, suggests a regional dynamic lull.

In the sections studied, the boundary between the Mykolaiv Sands and the Mid-Lithothamnian Horizon is put at the base of the first lithothamnian layer, continuous across each section ex- posed. Nevertheless, this almost barren horizon includes as well as such nektic elements as valves of small scallops, distinctive benthic elements. Apart from local oyster detritus, these are the polychaete tubes of Diopatra-type at Khorosno, and a "frozen" bed of Panopea bivalves buried in situ in life position at Khorosno (see Fig. 8) and Vybranivka. All occur at the basal part of the Mid-Lithothamnian Horizon, to demonstrate continuity of extremely shallow marine environmental conditions typical of the higher parts of the Mykolaiv Sands. The common thin-bedded planar stratification on these lithothamnian layers are reminiscent, though, of lacustrine or lagoonal rather than shallow open-marine sequences. Nowak (1938), in this context, suggested that the regional precipitation of calcium carbonate, involing profuse growth of lithothamnian red-algae, was in fact of evaporitic nature, preceding the formation of the Gypsum Series. This lies beyond the scope of the present paper, but the Mid-Lithothamnian Horizon seemingly formed under the same dynamic conditions as the Mykolaiv Sands, and its variable thickness was controlled by the uneven bottom topography formed by the topmost part of this sandbody.

The presence of the tropical/subtropical Indo-West Pacific biotic elements shows that the accumulation of the Mykolaiv Sands took place during the Langhian Climatic Optimum in early Badenian time. Their accumulation thus evidently took place prior to the Badenian Salinity Crisis (13.8 Ma: formation of Gypsum Series), which involved a dramatic drop in sea level, controlled by the tectonic evolution (nappe formation and orogenesis) of the Carpathian Range (Peryt, 2006). A primary control by the glacial event Mi-3b involving astronomical cycles, as recently envisaged by de Leeuw et al. (2010), may also be taken into account. The resulting drop in temperature and deprivation of thermophilic biota was a harbinger of the "Icehouse phase" in climatic records of the younger Neogene (see de Leeuw et al., 2010, p. 716 and fig. 3; cf. also Böhme, 2003, fig. 2). In consequence, the open-marine tropical/subtropical biota of the Indo-West Pacific provenance never returned to the Fore-Carpathian Basin. The biotic content of the Mykolaiv Sands, similar to that of the Medobory Biohermal Complex (see Radwański et al., 2006), remains thereby a captivating document of the "Greenhouse phase" (de Leeuw et al., 2010) of Neogene climate in Western Ukraine and the whole Fore-Carpathian Basin.

Acknowledgements. Cordial thanks are offered to the reviewers, Prof. Dr. A. Uchman (Jagiellonian University, Kraków) and Dr. K. Zágoršek (National Museum, Prague), as well as to Prof. Dr. T. Peryt (Polish Geological Institute - National Research Institute, Warszawa), whose constructive remarks have improved and enriched this paper. Cordially thanked is also Dr. M. Bieńkowska-Wasiluk for a kind donation of a shark tooth (see Fig. 9F). Fieldwork was partly supported by the Ministry of Science and Higher Education (Grant N 307 113635, of 2008-2011) and by the University of Warsaw (BSt 1536/2). 


\section{REFERENCES}

ALTH A. (1850) - Geognostisch-palaeontologische Beschreibung der nächsten Umgebung von Lemberg. Haidingers naturwiss., Abh. 3 (2): $171-279$.

BAŁUK W. and RADWAŃSKI A. (1977) - Organic communities and facies development of the Korytnica Basin (Middle Miocene; Holy Cross Mountains, Central Poland). Acta Geol. Pol., 27 (2): 85-123.

BAŁUK W. and RADWAŃSKI A. (1984) - New data on the Korytnica Basin, its organic communities and ecological relationships between species (Middle Miocene; Holy Cross Mountains, Central Poland). Acta Geol. Pol., 34 (3/4): 179-194.

BIEŃKOWSKA-WASILUK M. and RADWAŃSKI A. (2009) - A new occurrence of sharks in the Menilite Formation (Lower Oligocene) from Outer (Flysch) Carpathians of Poland. Acta Geol. Pol., 59 (2): 235-243.

BOUCOT A.J. (1990) - Evolutionary paleobiology of behavior and coevolution. Elsevier, Amsterdam-Oxford-New York-Tokyo.

BÖHME M. (2003) - The Miocene Climatic Optimum: evidence from ectothermic vertebrates of Central Europe. Palaeogeogr. Palaeoclimatol. Palaeoecol., 195: 389-401.

BUDKER P. (1971) - The life of sharks. Weidenfeld and Nicolson, London.

CAPPETTA H. (1987) - Chondrichthyes II: Mesozoic and Cenozoic Elasmobranchii. In: Handbook of Paleoichthyology (ed. H.-P. Schultze). Vol. 3B. Gustav Fischer Verlag, Stuttgart-New York.

De LEEUW A., BUKOWSKI K., KRIJGSMAN W. and KUIPER K.F. (2010) - Age of the Badenian salinity crisis; impact of Miocene climate variability on the circum-Mediterranean region. Geology, 38 (8): $715-718$

Des MOULINS C. (1875) - Cirrhipèdes pédonculés du terrain tertiaire miocène. Actes Soc. Linn. Bordeaux, Sér., 3 (10), 30: 131-173.

DULAI A. (1996) - Anterior fringe fragment of Clavagella (Bivalvia) from the Middle Miocene (Badenian) sandy deposits of Szob (Börzsöny Mts., Hungary). Fragmenta Miner. Paleol., 18: 71-78.

GOLDRING R., CADÉE G.C., D’ALESSANDRO A., de GIBERT J.M., JENKINS R. and POLLARD J.E. (2004) - Climatic control of trace fossil distribution in the marine realm. Spec. Publ. Geol. Soc., 228: 77-92.

HARZHAUSER M., MANDIC O. and ZUSCHIN M. (2003) - Changes in Paratethyan marine molluscs at the Early/Middle Miocene transition: diversity, palaeogeography and palaeoclimate. Acta Geol. Pol., 53 (4): 323-339.

HELLER C. (1858) - Über neue fossile Stelleriden. Sitzungsberichte der math.-naturwissen. Classe der kaiserlichen Akad. Wissensch., 28 (2): $155-170$.

HIGGINS R.C. (1974) - Specific status of Echinocardium cordatum, E. australe and E. zealandicum (Echinoidea: Spatangoida) around New Zealand, with comments on the relation of morphological variation to environment. J. Zoology, 173 (4): 451-475.

HILBER V. (1882) - Geologische Studien in den ostgalizischen Miocän-Gebieten. Jb. Kais. Kön. Geol. R.-A., 32 (2): 193-330.

HOWARD J.D. (1968) - X-ray radiography for examination of burrowing in sediments by marine invertebrate organisms. Sedimentology, 11 (3/4): 249-258.

JAHN A. (1937) - Morphological survey of the northern Podolian margin and ist foreground between the Kocurowski and Pohorylecki Stream. Kosmos A, 62 (4): 549-596.

KNER R. (1851) - Ueber den bei Lemberg vorkommenden Bernstein. Jhb. Geol. R.-A., 2: 163-164.

KROH A. (2005) - Echinoidea neogenica. Catalogus Fossilium Austriae, 2: 1-210. Österr. Akad. Wissensch., Wien.

KROH A. (2007) - Climate changes in the Early to Middle Miocene of the Central Paratethys and the origin of its echinoderm fauna. Palaeogeogr. Palaeoclimatol. Palaeoecol., 253: 169-207.

KUDRIN L.N. (1957a) - O paleoekologicheskikh issledovaniyakh otlozheniy nizhnego khorizonta nizhnego tortona yugo-zapadnoy okrainy Russkoy platformy. Geol. Sb. Lvovsk. Geol. Obshch., 4: 277-294.

KUDRIN L.N. (1957b) - O nakhodkakh zubov akul v otlozheniyakh miotsena yugo-zapadnoy okrainy Russkoy platformy. Geol. Sb. Lvovsk. Geol. Obshch., 4: 349.
KUDRIN L.N. (1966) - Stratigrafiya, fatsii i ekologicheskiy analiz fauny paleogenovykh i neogenovykh otlozheniy Predkarpat'ya. Izd. Lvovsk. Univ., Lvov.

KUDRIN L.N. and TATARINOV K.A. (1965) - O miotsenovykh del'finakh Zapadnoy Ukrainy. Paleontol. Zhurnal, 4: 68-74.

LERICHE M. (1957) - Les poissons néogènes de la Bretagne, de l'Anjou et de la Touraine. Mém. Soc. Géol. France, N. Sér., 36, Mém., 81: 1-61.

ŁOMNICKI A.M. (1897) - Atlas Geologiczny Galicyi. Tekst do zeszytu X, Część 1. Geologia Lwowa i okolicy. Komisya Fizyograficzna Akademii Umiejętności, Kraków.

ŁOMNICKI A.M. (1898) - Atlas Geologiczny Galicyi. Tekst do zeszytu dziesiątego, Część 2. Komisya Fizyograficzna Akademii Umiejętności, Kraków.

MALICKI A. and JAHN A. (1937) - The origin of the gravels occurring on the Northern Podolian margin and on southern Nadbuże (in Polish with English summary). Kosmos A, 62 (4): 597-611.

MANDIC O. (2004) - Pectinid bivalves from the Grund Formation (Lower Badenian, Middle Miocene, Alpine-Carpathian Foredeep) - taxonomic revision and stratigraphic significance. Geol. Carpath., 55 (2): 129-146.

MYERS A.C. (1970) - Some palaeoichnological observations on the tube of Diopatra cuprea (Bosc): Polychaeta, Onuphidae. Geol. J. Spec. Issue, 3: 331-334.

NEBELSICK J.H. (1995) - Actuopalaeontological investigations on echinoids: the potential for taphonomic interpretation. In: Echinoderm Research 1995 (eds. R. Emson, A. Smith and A. Campbell): 209-214. Proceedings of the Fourth European Echinoderms Colloquium. Balkema; Rotterdam/Brookfield.

NIEDŹWIEDZKI J. (1879) - Miocän am Südwest-Rande des galizisch-podolischen Plateaus. Verhandl. Geol. R.-A., 1879: 263-268.

NIEDŹWIEDZKI J. (1909) - Über eine neue miozäne Austernart: Ostrea leopolitana. Bull. Intern. Acad. Sc. Cracovie, Classe des Sc. Math. Nat., Année, 1908: 1073-1075.

NOWAK J. (1938) - Der Dniestr Fluss und die tortonen Gipse (in Polish with German summary). Rocz. Pol. Tow. Geol., 14: 155-194.

PAZDRO Z. (1953) - Jednostki tektoniczne w budowie Opola Małego i fazy ich rozwoju. Biul. Inst. Geol. (unnumbered issue): 1-114.

PERYT T.M. (2006) - The beginning, development and termination of the Middle Miocene Badenian salinity crisis in Central Paratethys. Sedim. Geol., 188-189: 379-396.

PERYT T.M. and PERYT D. (1994) - Badenian (Middle Miocene) Ratyn Limestone in western Ukraine and northern Moldavia: microfacies, calcareous nannoplankton and isotope geochemistry. Bull. Pol. Acad. Sc., Earth Sc., 42 (2): 127-136.

PETRYCZENKO O.I., PANOW G.M., PERYT T.M., SREBRODOLSKI B.I., POBEREŻSKI A.W. and KOWALEWICZ W.M. (1994) - Outline of geology of the Miocene evaporite formations of the Ukrainian part of the Carpathian Foredeep (in Polish). Prz. Geol., 42 (9): 734-737.

RADWAŃSKA U. (1992) - Fish otoliths in the Middle Miocene (Badenian) deposits of southern Poland. Acta Geol. Pol., 42 (3/4): 141-328.

RADWAŃSKI A. (1965) - A contribution to the knowledge of Miocene Elasmobranchii from Pińczów (Poland). Acta Palaeont. Pol., 10 (2): 267-276.

RADWAŃSKI A. (1973) - Lower Tortonian transgression onto the south-eastern and eastern slopes of the Holy Cross Mts. (in Polish with English summary). Acta Geol. Pol., 23 (2): 375-434.

RADWAŃSKI A. and WYSOCKA A. (2001) - Mass aggregation of Middle Miocene spine-coated echinoids Echinocardium and their integrated eco-taphonomy. Acta Geol. Pol., 51 (4): 295-316.

RADWAŃSKI A. and WYSOCKA A. (2004) - A farewell to Świniary sequence of mass-aggregated, spine-coated echinoids Psammechinus and their associates (Middle Miocene, Holy Cross Mountains, Central Poland). Acta Geol. Pol., 54 (3): 381-399. 
RADWAŃSKI A., GÓRKA M. and WYSOCKA A. (2006) - Middle Miocene coralgal facies at Maksymivka near Ternopil (Ukraine): a preliminary account. Acta Geol. Pol., 56 (1): 89-103.

RADWAŃSKI A., WYSOCKA A. and GÓRKA M. (2012) - Miocene burrows of the Ghost Crab Ocypode and their environmental significance (Mykolaiv Sands, Fore-Carpathian Basin, Ukraine). Acta Geol. Pol., 62 (2): 217-229.

REUSS A. (1864) - Über fossile Lepadiden. Sitzungsber. kais. Akad. Wissensch., Math.-Naturw. Classe, 49 (1): 1-32.

RÖGL F. and BRANDSTÄTTER F. (1993) - The foraminifera genus Amphistegina in the Korytnica Clays (Holy Cross Mts, Central Poland) and its significance in the Miocene of the Paratethys. Acta Geol. Pol., 43 (1/2): 121-146.

RÖGL F., ĆORIĆ S., HARZHAUSER M., JIMENEZ-MORENO G., KROH A., SCHULTZ O., WESSELY G. and ZORN I. (2008) - The Middle Miocene Badenian stratotype at Baden-Sooss (Lower Austria). Geol. Carpath., 59 (5): 367-374.

SCHULTZ O. (1998) - Tertiärfossilien Österreichs. Goldschneck, Korb.

SREBRODOLSKI B.I. (1980) - Yantar'Ukrainy. Naukova Dumka, Kiev.
SZÖRÉNYI E. (1953) - Miozäne Echinoiden aus den westlichen Teilen der Ukraine. Geol. Hung., Ser. Palaeont., 23: 1-122.

TEISSEYRE H. (1938) - Quelques observations sur la paléogéographie de Roztocze aux environs de Lwów (in Polish with French summary). Ann. Soc. Géol. Pol., 14: 113-154.

WEIMER R.J. and HOYT J.H. (1964) - Burrows of Callianassa major Say, geologic indicators of littoral and shallow neritic environments. J. Paleont., 38 (4): 761-767.

WITHERS T.H. (1953) - Catalogue of Fossil Cirripedia in the Department of Geology, Vol. $3 \mathbf{v}$ (Tertiary). British Museum (Natural History); London.

WYSOCKA A. (2002) - Clastic Badenian deposits and sedimentary environments of the Roztocze Hills across the Polish-Ukrainian border. Acta Geol. Pol., 52 (4): 535-561.

WYSOCKA A. and JASIONOWSKI M., eds. (2006) - Przebieg i zmienność sedymentacji w basenach przedgórskich. Materiały Konferencyjne II Polskiej Konferencji Sedymentologicznej. Zwierzyniec, 20-23.06.2006. 